\title{
KRAŠTOVAIZDŽIO ARCHITEKTĄ ANTANĄ TAURĄ (1912-1988) PRISIMENANT
}

\author{
Vaiva Deveikiené ${ }^{1}$, Steponas Deveikis ${ }^{2}$ \\ El.paštas: 1vaiva.deveikiene@vilnius.lt; ${ }^{2}$ steponas.deveikis@registrucentras.lt
}

2012 m. balandị sukako 100 metų nuo žymaus kraštovaizdžio architekto, ilgamečio dèsty tojo ir fakulteto dekano tuomečiame Vilniaus dailès institute (dabar Vilniaus dailès akademija) Antano Tauro (1912-1988) gimimo. Lietuvos gamtos apsaugos draugijos Garbès knygoje jo vardas buvo įrašytas greta prof. Tado Ivanausko, Viktoro Bergo ir kitų žymių gamtosaugos specialistų. Tokị ịvertinimą ir Tado Ivanausko premiją 1986 m. garbus kraštovaizdžio architektas pelnè už kraštovaizdžio apsaugos ir puoselèjimo, parkotyros nuopelnus.

Kai pasižiūri atgal, suvoki, kad Lietuvos kraštotvarkos pradmenys ir sovietiniu laikotarpiu buvo tvirti bei pamatuoti (tai, ko gero, visų pirma tuomečio Vilniaus inžinerinio statybos instituto Architektūros fakulteto ir Gyvenviečių planavimo ir tvarkymo (Urbanistikos) katedros kolektyvo nuopelnas), leidę suformuoti bei išsaugoti ir gamtinị, ir kultūrinị karkasą, mūsų valstybès savastị. Gamtos ir kultūros vienovès pojūtị stipriausiai yra išugdę kraštovaizdžio architektai, urbanistai, teritorijų planuotojai... Kraštovaizdžio architektas A. Tauras turèjo tokị pojūtị, tokị talentą. Jis daug prisidèjo prie architektūros ir kraštovaizdžio architektūros studijų išsaugojimo ir ugdymo Vilniaus dailès institute.

Antanas Tauras gimé $1912 \mathrm{~m}$. balandžio $19 \mathrm{~d}$. Purviniškès kaime, Marijampolès rajone. Kaune baigè Vytauto Didžiojo universitetą, ịgijo inžinieriaus architekto diplomą. 1937-1939 m. gilino žinias Paryžiuje, Sorbonos universiteto Urbanistikos institute. Modernioji romaninè prancūzų gyvenviečių planavimo tradicija suformavo jo kūrybinį kredo, gyvenimo ir darbo principus, pagarbą žmogui ir aplinkai, taktą ir profesinio bendravimo įgūdžius.

Sovietiniais pokario metais A. Tauras dirbo Vilniuje i̇vairiose projektavimo ịstaigose, vèliau - architektu Ministrų tarybos Architektūros reikalų komitete; nuo 1947 m. - Vilniaus dailès institute. Šiame institute jis dirbo iki $1982 \mathrm{~m}$. Vèliau iki pat gyvenimo pabaigos A. Tauras dirbo Architektų sąjungos ir Lietuvos gamtos apsaugos draugijos kraštovaizdžio architektūros mokslinèse komisijose. Dirbo nuolat keliaudamas, žiūrèdamas, stebėdamas, fiksuodamas.

Kalbant apie kraštovaizdžio architektą A. Taurą, pasakymas ,išvaikščiojo visą Lietuvą" nèra stereotipas ar tušti žodžiai. Tikrai išvaikščiojo ir parsinešè didžiulę patirti bei žinias, kurias mokejo dalinti studentams, kolegoms, mums visiems. Kraštovaizdžio architektas paliko mums ir minčiu, ir idejjų, ir konkrečiu projektų bei darbų: apie šimtą parkų ir skverų, gamtosaugos takų, kitokių kraštovaizdžio tvarkymo darbų buvo daroma pagal jo projektus, išleista daugiau kaip 10 knygų ir leidinių, išspausdinta daug straipsnių periodikoje, enciklopedijose. A. Tauras buvo plačiai žinomas specialistas, jis nestokojo leidyklų ir redakcijų bei skaity tojų dėmesio. Dalykiški architekto straipsniai spausdinti daugelyje to laiko periodinių leidinių („Girios“, „Mūsų gamta“ ir kt.). 1974 m. išleista solidi knyga - vadovèlis „Landšafto architektūra kaime“. Svarbiausių šio autoriaus publikacijų sąrašą pridedame straipsnio pabaigoje.

Savo knygose autorius dèstė kraštovaizdžio architektūros postulatus, glaustais pavyzdžių aprašymais ir iliustracijomis - fotonuotraukomis, piešiniais formavo visuomenès skonį ir specialistų nuostatas. Daugiausia dèmesio A. Tauras skyrè seniesiems ir naujiesiems Lietuvos parkams, apie juos išleido dvi knygas (1966 ir 1989). Paskutinè knyga „Mūsų parkai“ išleista jau po autoriaus mirties, parašyta remiantis 1981-1984 (1986) m. Gamtos apsaugos komiteto su socialiniais partneriais atliktos parkų inventorizacijos medžiaga ir duomenimis. Abiejose knygose pateikiamos apžvalginès parkų schemos ir vietovaizdžių eskizai, suvestinès parkų rodyklès, retųjų medžių radimvietès ar augavietès. Pirmosios (1958) ir vèlesnès (1984) parkų invento- 
a

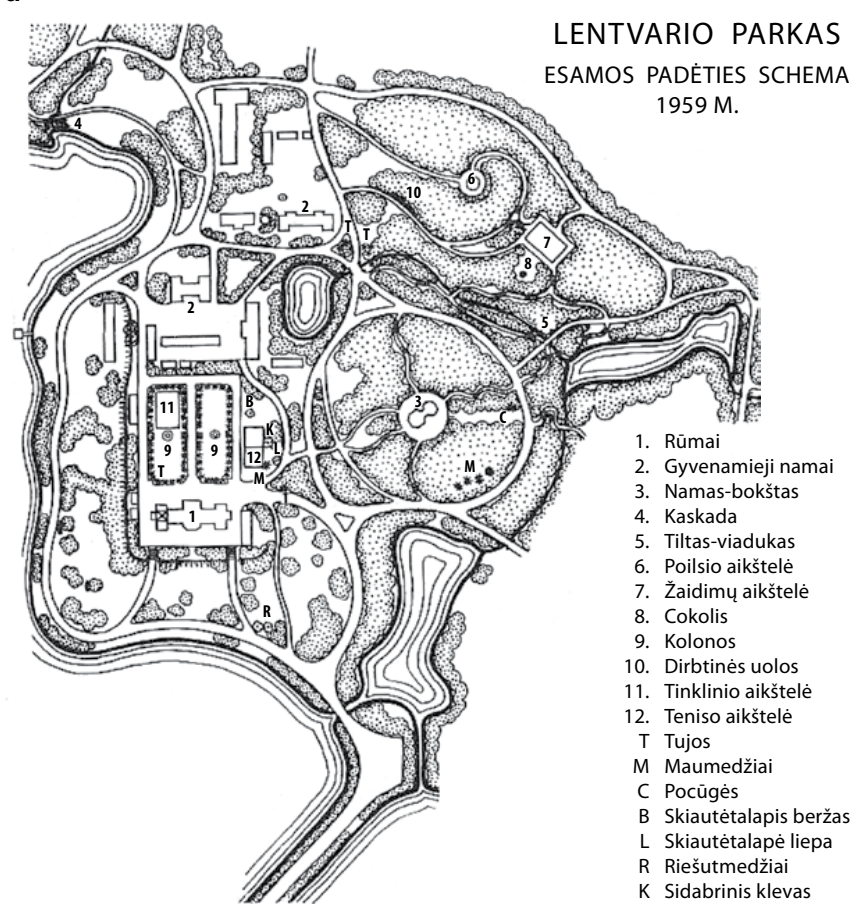

b

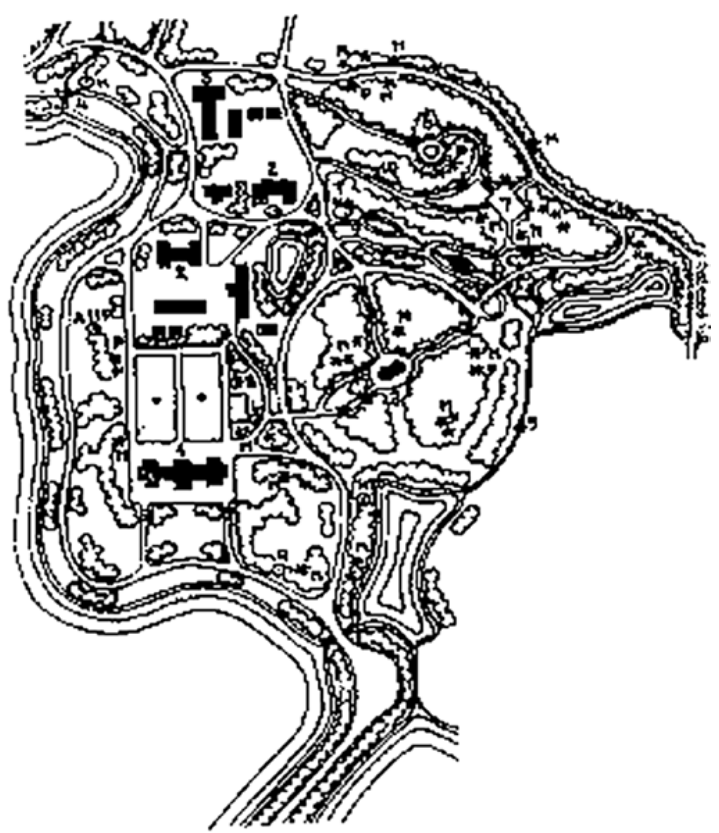

Kraštovaizdžio architekto A. Tauro sudaryti Lentvario dvaro parko planai: a - iš $1966 \mathrm{~m}$. leidinio pagal $1959 \mathrm{~m}$. parku inventorizacijos duomenis; b - iš 1989 m. leidinio pagal 1983-1986 m. parkų inventorizacijos duomenis

rizacijos schemos ilgą laiką buvo ir dabar tuo labiau lieka labai svarbus informacijos apie senuosius ir XX a. sukurtus parkus šaltinis (Lietuvos parkų schemos 2012). Knygose autorius paminèjo ne tik savo projektuotus Buivydiškių (1965), Girionių (1960), Meškuičių, Rečionių, Žiežmarių, bet ir kitų autorių projektuotus parkus.

Parkotyra Lietuvoje, ypač devintajame ir dešimtajame XX a. dešimtmečiuose ir vèliau, gerokai pažengè ir patobulèjo. Gamtos ir kultūros visetas (koks visada yra parkas) reikalauja kompleksiško požiūrio, daugelio specialistų pastangų ir apima gamtos bei meno filosofiją, geomorfologiją ir hidrologiją, botaniką ir dendrologiją, inžinerinius bei estetinius, kraštovaizdžio formavimo, architektūros ir ekologijos dalykus. A. Tauras nebuvo dendrologas ar hidrotechnikas, bet jis nuostabiai jaute architektonikos dalykus, išlavinta ranka ir būdingu piešiniu galèjo modeliuoti aplinką ir atskleisti, kaip jis saké, „kultūrinio landšafto grožị ‘.

Su šiuo architektu yra tekę bendrauti daugeliui vyresnès kartos kraštovaizdžio architektų ir gamtosaugos specialistų. Visiems tai buvo puiki gyvenimo ir meno pajautos mokykla. Lietuvos kraštovaizdžio tvarkytojai turètų nuolat prisiminti taurias kraštovaizdžio architekto A. Tauro idejas, mintis ir konkrečius darbus parkuose, gyvenvietèse ir švietimo baruose.
A. Tauro pastebejimai ir mintys vis dar cituojamos. Pavyzdžiui, kad ir Gelgaudiškio parko aprašymuose vis nurodoma, kad prieš pusšimtị (o dabar jau ir 60) metų A. Tauras čia suskaičiavo 11 terasų, išdèstytų kas $1,5 \mathrm{~m}$ viena žemiau kitos. Draugijos "Jungès“ tinklalapis www.manoparkas.lt publikuoja daugelį A. Tauro sudarytų parkų schemų iš 1989 m. leidinio „Mūsų parkai“. Kraštovaizdžio architekto sudarytų parkų schemų informacija pranoksta daugelio šiuolaikinių parkotyros darbų autorių opusus ir yra puikus pagrindas parkams pažinti ir tirti.

Pabaigoje pateikiame keletą ištraukų iš A. Tauro publikacijų - manome, kad tos mintys tebera aktualios ir šiandien.

„Tvarkydami parko želdinius, turètume būtinai atkurti pievinius gazonus, užsèdami juos varpinemis žolemis. Reikia atminti, kad švari, sistemingai šienaujama veja yra sveikiausias ir patraukliausias atvirų erdvių pagrindas, kurio būklè liudija apie žaliosios aplinkos tvarkymo kultūrą" (Tarybų darbas, 1985, Nr. 11, p. 30).

„Tiesiant naujus bei rekonstruojant senus kelius, turètų būti išspręsti ne tik jų ịderinimo ị landšaftą, sankasos bei dangos įrengimo ir eksploatacijos klausimai, bet taip pat kelių aplinkos sutvarkymas, nes aplinka daro didelị poveikị vairuotojų ir keleivių savijautai. Atitinkamose pakelių vietose būna tikslinga 
pasodinti želdinių derinius, kurie išryškintų kelio trasą, t. y. posūkių ir nuolydžių išsidėstymo ritmą, taip pat uždengtų nepatraukliai atrodančius pakelès statinius ar įrenginius. Paminètų darbų kompleksą gali tinkamai ìvykdyti tik kelininkai“ (Kultūrinio landšafto grožis, 1979, p. 21).

\section{Literatūra ir šaltiniai}

Deveikis, S. 2002. Antano Tauro ir mūsų parkai, Žemètvarka ir hidrotechnika 2: 100-102.

Mačiulis, A. 2011. Vytautas Edmundas Čekanauskas. Vilnius: VDA leidykla: 18, 20, 21, 29, 182.

Lietuvos parku schemos [žiūrèta 2012-10-15]. Prieiga per internetą: www.manoparkas.lt (draugija "Jungès").

\section{Svarbiausios Antano Tauro (1912-1988)}

publikacijos

1. Lietuvos TSR parkai. 1966. Vilnius.

2. Grožis mūsų kaime. 1971. Vilnius: Mintis.

3. Land šafto architektūra kaime. 1974. Vilnius: Mintis

4. Kultūrinio landšafto grožis. 1979. Vilnius: Mokslas.

5. Mūsu parkai. 1989. Vilnius: Mokslas.

6. Straipsnių ciklas apie miško parkus, jų kūrimą ir formavimą, Girios. 1974, Nr. 5: 12-13; Nr. 6: 14-15; Nr. 7: 12-13. 